\title{
Physical attributes of Humic Cambisol subjected to nitrogen sources in an apple orchard
}

\author{
Daniela Schmitz', Arcângelo Loss ${ }^{*}$, Cledimar Rogério Lourenzi', \\ Vilmar Müller Júnior', Milton da Veiga², Gustavo Brunetto³, Jucinei José Comin'
}

\footnotetext{
'Federal University of Santa Catarina, Florianópolis, SC, Brazil

2University of West Santa Catarina, Campos Novos, SC, Brazil 3Federal University of Santa Maria, Santa Maria, RS, Brazil

*Corresponding author, e-mail: arcangelo.loss@ufsc.br
}

\begin{abstract}
The application of nitrogen sources in soil under apple orchards can change the soil physical attributes and soil-plant relationship. The objective was to evaluate the physical attributes of Humic Cambisol (Inceptisol) in an apple orchard, under nitrogen sources in Urubici county, Santa Carina State, Brazil. The treatments were: control (without fertilization), common urea, pelleted urea and organic fertilizer (pig deep-litter), at rates of $33 \mathrm{~kg} \mathrm{~N} \mathrm{ha}^{-1} \mathrm{yr}^{-1}$. After two years of implementation of the $\mathrm{N}$ sources, soil undisturbed samples were collected at layers of 0.0$0.05,0.05-0.10,0.10-0.15$ and $0.15-0.20 \mathrm{~m}$ depth, and these were evaluated the bulk density (BD); penetration resistance (PR); total porosity, macro, meso, and micropores; the geometric mean diameter of air-dried aggregates (GMDad) and water-stable aggregates (GMDws) and water content. The organic fertilizer increased the total porosity, microporosity, the water content and decreased BD, compared to other treatments, at the layer of 0.0-0.05 m depth. The organic fertilization and the common urea did not change the macroporosity and PR, but provided lower macroporosity, compared to the control, and RP in relation to pelleted urea. The $\mathrm{N}$ sources increased GMDws compared with the control in the topsoil.
\end{abstract}

Keywords: : bulk density, penetration resistance, geometric mean diameter, pelleted urea, pig deeplitter

\section{Introduction}

Brazilian apple production is concentrated in the South of the country, with Rio Grande do Sul state holding 52\% of the national production and Santa Catarina state (SC) as the second largest producer, with $43 \%$ of production (ACATE, 2014). In SC, production is concentrated in the regions of Planalto Serrano - in the cities of São Joaquim, Bom Jardim da Serra, Bom Retiro, Urubici and Urupema - and in the midwest - in the cities of Fraiburgo, Monte Carlo, Água Doce and Lebon Régis (IBGE, 2011), due to the climate being favorable to the good performance of the cultivars used in these regions.

Much of the Brazilian apple production is carried out in the conventional system of cultivation, which is dependent on chemical inputs, such as nitrogenous, generating environmental impacts, such as contamination of the waterground due to leaching, mainly, of nitrate, and increasing of gasses in the atmosphere (nitrous oxide) by volatilization and, or, denitrification. The use of the organic system is an alternative, since it aims at the nutrient supply and excludes the use of soluble fertilizers (Peck et al., 2011; Holb et al., 2012; Amarante et al., 2015). The differences between these systems may influence attributes related to soil quality, such as physical ones, addition to reflect directly and indirectly on the crop yield. (Oliveira et al., 2014; 
Amarante et al., 2015).

Studies using different nitrogen sources in apple orchards evaluated fruit yield and quality, as well as soil chemical attributes (MalucheBaretta et al., 2007; Martins et al., 2008; Oliveira et al., 2014). However, these authors did not evaluate the soil physical attributes, such as soil porosity, soil aggregation, soil bulk density and soil penetration resistance. These attributes are related to soil physical quality, which can affect the water flow and nutrients, and reduce the crop yield (Silva et al., 2006).

The soil physical quality is defined by the interaction of its attributes, for instance, organic matter is an important structuring agent, participating in the formation and stabilization of the soil aggregates (Bronick e Lal, 2005), being considered one of the constituents responsible for maintaining the soil physical quality (Vezzani e Mielniczuk, 2009). By decreasing the soil organic matter content (SOM), it is expected that there will be a loss in the soil physical quality. A practice that may result in the reduction of SOM is the fertilization with mineral nitrogen, for example, urea, since this nitrogen becomes raw material for decomposer microorganisms, accelerating the decomposition of SOM (Souza et al., 2013).

An alternative is the use of slow-release nitrogen sources, such as pelleted urea and organic sources, such as pig deep-litter. The organic sources still bring different results, as there are cases in which an increase of soil macroporosity was observed, with consequent decreasing of soil bulk density (Andreola et al., 2000; Comin et al., 2013), as well as greater soil aggregate stability (Comin et al., 2013). Other studies did not find changes in soil bulk density, porosity and stability of soil aggregates (Espanhol et al., 2007) and still, it was verified that the application of pig manure reduced the stability of soil aggregates (Arruda et al., 2010). Therefore, more studies are needed in order to obtain more consistent results regarding the effects of different $\mathrm{N}$ sources, mainly pig manure, on the soil physical attributes.

The present study aimed to evaluate the soil physical attributes of a Humic Cambisol in an apple orchard submitted to application of different sources of nitrogen fertilization in Urubici county, sC.

\section{Materials and Methods}

The experiment was carried out in Urubici County, located in Planalto Serrano region, Santa Catarina state (SC), Brazil, in a commercial orchard established in 2008, composed of two apple varieties, Fugi and Gala, in the proportion of 30 and $70 \%$, respectively. Only plants of the cultivar Gala were selected in this experiment. The orchard was conducted in a planting system with a central leader with a betweenrow spacing of $4.5 \mathrm{~m}$ and the distance between plants within the row was $1.5 \mathrm{~m}$. The plants were grafted on the Marubakaido rootstock. The soil of the orchards was classified as Cambisol Humic (Inceptisol) medium texture (Embrapa, 2013) and according to the classification of KöppenGeiger, the climate of the region belongs to $\mathrm{Cfb}$ type. Before starting the experiment, at the layer of $0.0-0.20 \mathrm{~m}$ depth, the following parameters were verified (Table 1).

From October 2011, 80 plants received different sources of nitrogen fertilization, forming the following treatments: control (without nitrogen fertilization), fertilization with urea ( $45 \%$ of total $N$ ), fertilization with pelleted urea ( $41 \%$ of total N) and organic fertilization, which consisted of pig deeplitter (1.3\% of total N). The doses of each source of $\mathrm{N}$ were calculated to apply $33 \mathrm{~kg} \mathrm{ha}^{-1}$ year-1 of $\mathrm{N}$, divided into two doses of $16.5 \mathrm{~kg} \mathrm{ha}^{-1}$ of $\mathrm{N}$ each, the first application was carried out at the beginning of apple tree bloom (October) and the second one at the beginning of dormancy (June) (CQFS-RS/SC, 2004). The experiment was arranged in a randomized block design with four replication, where each replicate was formed by five apple plants.

Table 1. Soil chemical attributes and soil texture at the layer of 0.0-0.20 m depth.

\begin{tabular}{lccccccccc}
\hline $\mathrm{pH}$ & $\mathrm{Ca}$ & $\mathrm{Mg}$ & $\mathrm{Al}$ & $\mathrm{SOM}$ & $\mathrm{P}$ & $\mathrm{K}$ & Sand & Silt & Clay \\
\hline$\left(\mathrm{H}_{2} \mathrm{O}\right)$ & $-------\mathrm{Cmol}_{\mathrm{c}} \mathrm{dm}^{-3}-------$ & $\mathrm{g} \mathrm{kg}^{-1}$ & $----\mathrm{mg} \mathrm{kg}^{-1}----$ & $-------\mathrm{g} \mathrm{kg}^{-1}-$------- \\
\hline 5.80 & 8.5 & 3.20 & 0.0 & 46 & 32 & 243 & 462 & 299 & 239 \\
\hline SOM = soil organic matter & & & & & & & &
\end{tabular}

$$
\text { SOM = soil organic matter }
$$


Fertilization was carried out on the soil surface under the canopy of the apple trees, without incorporation. The control of spontaneous plants in all treatments was carried out with non-residual herbicide, whose active principle is potassium glyphosate, dilution of $50 \mathrm{~mL} 20 \mathrm{~L}^{-1}$ and application of $500 \mathrm{~L} \mathrm{ha}^{-1}$. The average yield values of apple in the $2011 / 2013$ harvests was 22.8; $29.6 ; 24.8$ and $29.0 \mathrm{Mg} \mathrm{ha}^{-1}$, for the control treatment, common urea, pelleted urea and organic fertilization, respectively. (Oliveira et al., 2014).

In January 2014, soil samples were collected in order to perform soil physical analysis according to Veiga (2011), opening trenches in the projection of the apple tree (in the line) located in the centre of the block, distanced $0.20 \mathrm{~m}$ from the tree stem, where undisturbed soil cores $(0.05 \mathrm{~m}$ in diameter and $0.05 \mathrm{~m}$ in height) were collected at the layers 0.0-0.05; 0.05-0.10; 0.10-0.15 and 0.15-0.20 m depth. Afterward, the samples were sealed and sent to the Soil Physics Laboratory, following the methodology described by Veiga (2011).

The samples were submitted to a series of analyses. At first, the soil samples were saturated by capillarity, being placed in a container that water was added until reaching half the height of the metallic ring, remaining in that condition for $24 \mathrm{~h}$ until the entire sample has been saturated. The weight of the saturated samples was then measured.

In order to obtain the soil water retention curve, the saturated samples were placed on the tension table and submit them to the tensions of 0,6 and $6 \mathrm{kPa}$ matric potential, afterward, the pressure plate apparatus (Richards) was used at matric potentials of 60 and $600 \mathrm{kPa}$. At the end of the application of each tension (matric potential), the weight of the sample was measured and the next tension was performed. The pore size distribution was determined by using the specific matric potentials. The macropores, with a diameter greater than or equal to $50 \mu \mathrm{m}$, retain saturated soil water up to $6 \mathrm{kPa}$ matric potential, mesopores, which have diameters between 50 and $5 \mu \mathrm{m}$, retain water between 6 and $600 \mathrm{kPa}$ matric potentials, and micropores, which have diameters smaller than $5 \mu \mathrm{m}$, retain water that has not been removed up to $600 \mathrm{kPa}$ matric potential.

Soil penetration resistance was performed using a Marconi bench penetrometer model MA933 equipped with $80 \mathrm{~mm}$ high penetration pin, a diameter $(\varnothing)$ of less than 3 $\mathrm{mm}$, a diameter $(\varnothing)$ of more than $4 \mathrm{~mm}$ and 30 degrees angular conical tip, and it was adjusted for a penetration velocity of $1 \mathrm{~mm} \mathrm{~s}^{-1}$. The value for each sample corresponds to the average of the 30 values obtained between 11 and $40 \mathrm{~mm}$ depth. The soil penetration resistance was determined at the center of the same samples used to determine soil bulk density and porosity (internal $\varnothing=70 \mathrm{~mm}$ and $\mathrm{h}$ $=50 \mathrm{~mm}$ ), with balanced/stabilized moisture at the $600 \mathrm{kPa}$ potential matric using the pressure plate apparatus (Richards). After this sequence of analyses, the samples that until then had their structure preserved (undisturbed samples), passed to a second stage, where they became to be deformed (disturbed samples).

The soil bulk density was then determined by removing $20 \mathrm{~g}$ of the sample and drying it in a stove at $105^{\circ} \mathrm{C}$ for $24 \mathrm{~h}$ to complete evaporation of all water. Secondly, the stability of soil aggregates was determined by the size distribution of the air-dry aggregates. The soil sample was removed from the metal ring and broken until the entire sample passed through an $8 \mathrm{~mm}$ mesh, then the soil aggregates were the air dried until the moisture being stabilized. Subsequently, the soil was sieved in 4, 2, 1, 0.5 $\mathrm{mm}$ meshes, then the soil retained in each mesh and the soil retained in the bottom of sieve was weighed to compose the aggregate size data.

The stable aggregates in water were determined by the aggregates retained in each mesh. The soil aggregates were placed on the meshes of the sieves with the same diameters as the previous determination and then the sieves were positioned inside the equipment where the sieving was carried out, adding water until it touched the bottom of the upper mesh, keeping them in this condition for $10 \mathrm{~min}$. Thereafter, the equipment was turned on for a further $10 \mathrm{~min}$, promoting mild agitation. At the end, the sieves were removed, each containing a class of soil aggregates that, to be quantified were dried at 
$105^{\circ} \mathrm{C}$. The masses of the aggregates retained in the classes of $\varnothing$ : $<0.5,0.5-1.0,1.0-2.0$ and 2.0$4.0 \mathrm{~mm}$ were used to determine the geometric mean diameter of air-dried aggregates (GMDad) and water-stable aggregates (GMDws), using equation (1):

$$
D M G=\exp \left[\sum_{i=1}^{n}(p i * \ln d i]\right.
$$

where $\boldsymbol{i}$ represents the class of soil aggregates (8-4, 4-2, 2-1, 1-0.5 and <0.5 mm); pi is the proportion of soil aggregates present in the respective class in relation to the total mass of soil aggregates; $\mathbf{L} \boldsymbol{n}$ is the Neperian logarithm; and $\boldsymbol{d}$ is the mean diameter of the class (respectively 6 , $3,1.5,0.75$ and $0.25 \mathrm{~mm}$ ).

Lilliefors and Bartlett's test were used to analyze the normality and homogeneity of variance of the data, respectively. Afterward, the variance analysis was performed using the $\mathrm{F}$ test to bifactorial, the treatments and layers being the two factors and, if statistical differences were detected, the Tukey test was applied at 5\% ( $p<0$, 05) using the software ASSISTAT (Beta Version 7.7). The interaction was sliced when it was verified interaction between the factors. When there was no significant interaction, it was proceeded to analyze the isolated factors.

\section{Results and Discussion}

The soil total porosity and microporosity showed the interaction between the evaluated factors, whereby the organic treatment showed average values higher than the other treatments in the superficial layer (0.0-0.05 m) and higher than average values of the subsequent layers. The control treatment showed microporosity values at the layer of $0.15-0.20 \mathrm{~m}$ depth higher than those at the layer of 0.0-0.05 $\mathrm{m}$ depth. There were no differences between treatments for soil total porosity and microporosity at the layers of 0.05-0.10, 0.10-0.15 and 0.15-0.20 m depth (Figure 1).

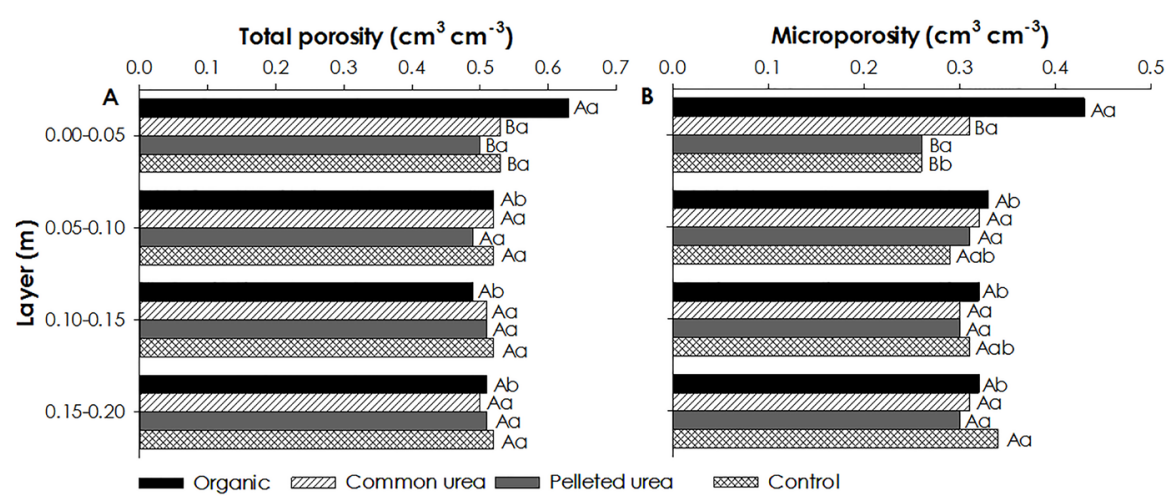

Figure 1. Sliced interaction between treatment and layer for soil total porosity (A) and microporosity (B). Average values sharing the same capital letter do not differ within the same layer and average values sharing the same lowercase letter do not differ within the same treatment (Tukey $p<0,05)$.

The highest values of soil porosity (total and microporous) in the organic treatment were due to the use of pig deep-litter since this organic material will stimulate the microbial processes that help to develop and maintain the soil aggregates and soil structure, contributing to the resistance to soil degradation. (Glover et al., 2000; Comin et al., 2013) and, consequently, increasing the organic matter content, as well as the soil porosity, due to the lowest values of soil bulk density in this treatment (Figure 2). The highest soil microporosity in the control treatment at the layer of $0.15-0.20 \mathrm{~cm}$ depth may be due to the increase of soil bulk density at this treatment
(Figure 2), as soil macroporosity decreases in depth (Table 2).

There was no interaction between the factors for the macro and mesoporosity, as well as for soil penetration resistance (PR). However, for isolated factors responses were observed (Table 2). The highest macroporosity average values were observed in the control treatment and the lowest in treatments with pig deep-litter and common urea. Treatment with pelleted urea obtained intermediate average values comparing to the other treatments. In relation to the layers, higher average values were observed only in the superficial layer. 
Table 2. Average values of soil macroporosity, mesoporosity, penetration resistance (PR) for treatment and layer factors.

\begin{tabular}{|c|c|c|c|}
\hline & $\begin{array}{c}\text { Macroporosity } \\
\left(\mathrm{cm}^{3} \mathrm{~cm}^{-3}\right)\end{array}$ & $\begin{array}{c}\text { Mesoporosity } \\
\left(\mathrm{cm}^{3} \mathrm{~cm}^{-3}\right)\end{array}$ & $\mathrm{PR}(\mathrm{MPa})$ \\
\hline \multicolumn{4}{|l|}{ Treatments } \\
\hline Organic & $0.13 \mathrm{~B}$ & 0.06 & $2.43 \mathrm{~B}$ \\
\hline Common Urea & $0.13 B$ & 0.06 & $2.44 \mathrm{~B}$ \\
\hline Pelleted urea & $0.15 \mathrm{AB}$ & 0.06 & $3.13 \mathrm{~A}$ \\
\hline Control & $0.16 \mathrm{~A}$ & 0.06 & $2.8 \mathrm{AB}$ \\
\hline F test & $4.06^{*}$ & $0.78^{\mathrm{NS}}$ & $10.86^{* *}$ \\
\hline \multicolumn{4}{|l|}{ Layers } \\
\hline $0-5 \mathrm{~cm}$ & $0.18 \mathrm{~A}$ & 0.06 & 2.72 \\
\hline $5-10 \mathrm{~cm}$ & $0.14 \mathrm{~B}$ & 0.06 & 2.79 \\
\hline $10-15 \mathrm{~cm}$ & $0.14 \mathrm{~B}$ & 0.06 & 2.66 \\
\hline $15-20 \mathrm{~cm}$ & $0.13 \mathrm{~B}$ & 0.05 & 2.63 \\
\hline F teste & $7.80 * *$ & $2.08^{\mathrm{NS}}$ & $0.51^{\mathrm{NS}}$ \\
\hline CV (\%) & 19.32 & 19.93 & 14.97 \\
\hline
\end{tabular}

The highest values of soil macropores in the control treatment can be due to the effect of the vegetation cover added to the lesser anthropogenic action (human trampling) in this area, since in the other treatments the application of the nitrogen sources is carried out twice a year, whereby the first application was carried out at the beginning of apple tree bloom (October) and the second one at the beginning of dormancy (June). The highest values of soil macropores in the control treatment are according to the lowest values of soil bulk density in comparison to the common urea treatment (Figure 2).

The soil macroporosity values in all treatments were adequate, that is, neither the root growth nor water and air flowing is being affected, since the macroporosity values were lower than the critical level $\left(0.10 \mathrm{~m}^{3} \mathrm{~m}^{-3}\right.$ ) (Arruda et al., 2010; Moreti et al., 2006; Richart et al., 2005; Silva et al., 2006). Regarding the size of intermediate pores (mesoporosity), there were no effects of the treatments and layers (Table 2).

It was not detect statistical differences for soil total porosity, macroporosity and microporosity in studies such as those conducted by Arruda et al. (2010), under no-tillage system (NTS) with oat/corn succession under a Red Latosol (Oxisol), with control treatment; urea treatment (140 kg ha-1) and pig slurry treatment applied at doses of 50, 100 and $200 \mathrm{~m}^{3} \mathrm{ha}^{-1}$; and Moreti et al. (2006), in NTS and conventional tillage under a Red Latosol (Oxisol) with crop rotation of corn, bean and cotton fertilized with chicken manure (14 $\left.\mathrm{Mg} \mathrm{ha}^{-1}\right)$, chemical fertilization (according to culture) and control treatment. However, Andreola et al. (2000), in a study with mineral fertilization (urea) and organic (poultry manure) in corn/bean succession using forage turnip and oat as cover plants, observed a reduction of soil macroporosity, independently of the $\mathrm{N}$ source used, corroborating with the results that were observed in the organic and common urea treatments, and an increase in soil microporosity, a fact only observed for organic treatment (Figure 1). In addition, Bronick and Lal (2005) also pointed to increase the total porosity in soils fertilized with organic sources.

For the pore distribution classes, it was observed that the soil macroporosity decreased in depth, corroborating with the data presented by Andreola et al. (2000) and Espanhol et al. (2007). However, these authors found that the soil microporosity increased in depth, which only occurred in the control treatment for the present study. The micropore average values maintained stable in depth for the urea treatments, whereas in the organic treatment, a decrease of the microporosity in depth it was observed.

Soil bulk density (Bd) showed the interaction between the treatments and the layers, that the lowest average values were found in the organic treatments, followed by the control, pelleted urea and common 
urea treatments $(0.0-0.05 \mathrm{~m})$. In relation to the layers, only the organic and control treatments presented differences, showing the lowest values at the superficial layer, whereas for the control treatment, equal values were also verified at the layer of 0.05-0.10 m depth (Figure 2).

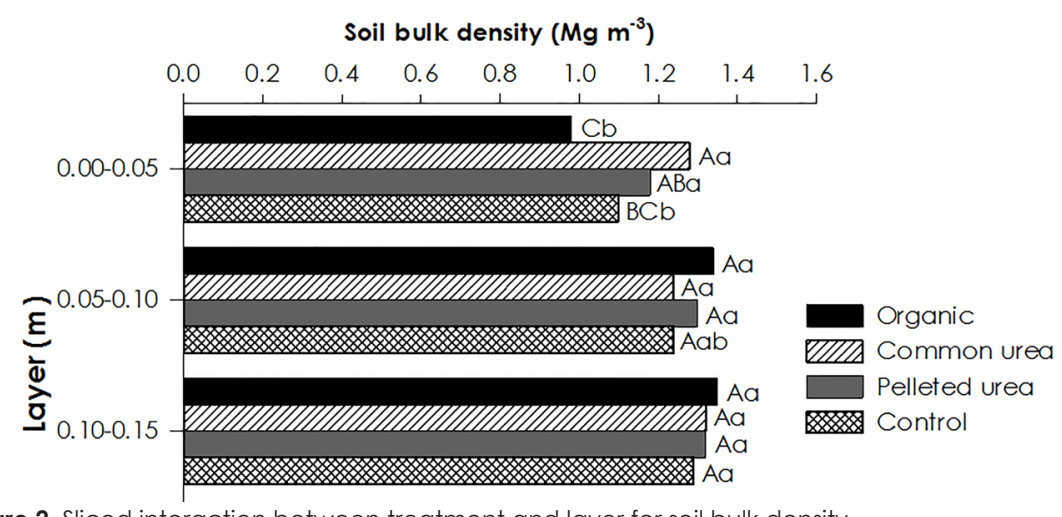

Figure 2. Sliced interaction between treatment and layer for soil bulk density.

In some studies, no differences were found for the average values of $\mathrm{Bd}$ when the soil was submitted to mineral and organic fertilization sources, such as those developed by Arruda et al. (2010) and Espanhol et al. (2007). However, there are studies that corroborate with the results of the present study, showing that the use of organic residues promotes a reduction in Bd, mainly, at the superficial layers (Andreola et al., 2000; Comin et al., 2013). These same authors pointed out that the decreasing of $\mathrm{Bd}$ is related to the increase of macroporosity and the decreasing of microporosity, a fact that was not observed in the present study. However, the soil porosity is not the only way to explain the change in soil bulk density. In this way, Bronick e Lal (2005), Luciano et al. (2014) and Richart et al. (2005) attributed the lowest Bd to the greatest presence of organic material at the superficial layers of the soil, especially when the applications of the organic sources occur superficially without the incorporation to the soil. Moreover, according to Richart et al. (2005), this is due to the fact that the organic matter has a density of approximately 2.5 times less than the other constituents of the soil.

Similar results to this study were reported by Comin et al. (2013), in which the authors found lower Bd values $\left(0.99 \mathrm{Mg} \mathrm{m}^{-3}\right)$ at the layer of $0-5 \mathrm{~cm}$ depth in a soil under NTS fertilized with pig deep-litter for 10 years in comparison to the control treatment without addition of pig deeplitter, which showed $\mathrm{Bd}$ value equal to $1.17 \mathrm{Mg}$ $\mathrm{m}^{-3}$. These authors also report that the lowest $\mathrm{Bd}$ values in the organic treatment fertilized with pig deep-litter were directly related to the highest soil pores values (macro, micro, and total porosity) found in this treatment. These results corroborate those of the present study, which the lowest $\mathrm{Bd}$ values were also found in the organic treatment, besides showed higher pore values (macro and total porosity).

The lowest average values of penetration resistance (PR) were observed for organic treatment and common urea treatment, whereas the highest PR average values were observed for pelleted urea treatment. The control treatment showed intermediate mean values (Table 2). As described by Moreti et al. (2006), it was also not possible to distinguish the influence of organic and mineral fertilization, since, for mineral fertilization, the common urea showed results equal to the treatment with organic fertilization, however PR values in common urea treatment were lower than those found in pelleted urea treatment. However, the same authors found a lower PR in depth, which did not occur in the present study.

The lowest RP values in the organic treatment may be due to the lowest Bd values (Figure 2) and the highest geometric mean diameter of air-dried aggregates (GMDad) values (Figure 3) at the superficial layer (0.0$0.05 \mathrm{~m}$ ), corroborating also with the highest total porosity and microporosity values found in this treatment (Figure 1). Some authors have shown that lower Bd values and higher aggregation (GMDad) may result in lower PR values (Comin et al., 2013; Luciano et al., 2014). 


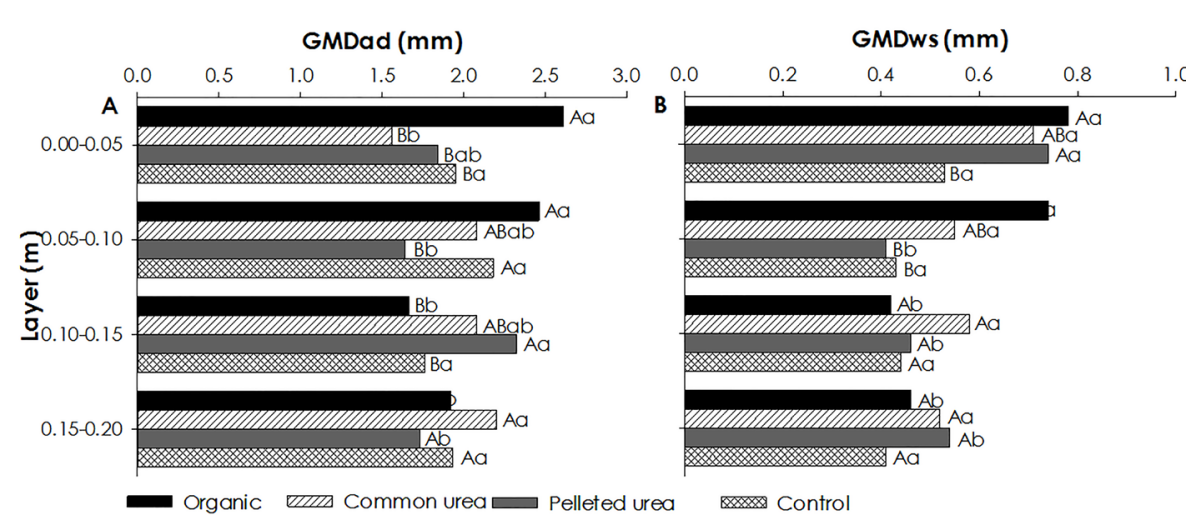

Figure 3. Sliced interaction between treatment and layer for the geometric mean diameter of airdried aggregates (GMDad) (A) and water-stable aggregates (GMDws) (B). Average values sharing the same capital letter do not differ within the same layer and average values sharing the same lowercase letter do not differ within the same treatment (Tukey $\mathrm{p}<0.05$ ).

For GMDad and GMDws, there was an interaction between the factors (Figure 3). For the GMDad, the highest average values were observed in the organic treatment, at the layer of 0.0-0.05 m depth, and organic and control treatments, at the layer of $0.05-0.10 \mathrm{~m}$ depth, whereas the highest values at the layer of 0,10 $0.15 \mathrm{~m}$ depth were verified in the pelleted urea treatment. The only treatment that remained stable in depth was the control, and treatment with common urea showed an increase in GMDad in depth. The GMDws values showed a decrease in depth, except for the control treatment. Among the treatments, the control showed the lowest GMDws values at the layer of 0.05-0.10 and 0.05-0.10 m depth, which this latter layer being equal to that with pelleted urea treatment. The organic treatment showed the highest GMDws values at the layer of 0.0-0.10 m depth comparing to the control and to pelleted urea at the layer of 0.05-0.10 m depth (Figure 3).

In contrast to the results found by Arruda et al. (2010) and Espanhol et al. (2007), but corroborating with those found by Bronick and Lal (2005) and Comin et al. (2013), the organic fertilization contributed to the increase of the geometric mean diameter. Higher GMD values found in the superficial layer and subsequent decreasing in depth were verified by other authors as well (Espanhol et al., 2007; Comin et al., 2013), indicating a decrease of cementing agents, such as organic matter.

According to Carey et al. (2009), the presence of stable aggregates, indicated by the highest values of GMDad and GMDws, increases resistance to erosion, water availability, root growth, flowing of liquids and organic and inorganic substances and diffusion of gasses, so providing an improvement in soil quality. In this way, the organic treatment can be highlighted, which showed higher GMDad and GMDws values at the layer of 0.0-0.05 $\mathrm{m}$ depth, and for the GMDws the difference is only in comparison with the control treatment. In addition to the highest aggregation rates, the organic treatment also showed the highest values of total porosity, which promote water flowing and gas diffusion; and the highest microporosity values, which promote water flowing. These results are in agreement with those found by Amarante et al. (AGG) who verified the highest GMD and total porosity values, as well as the lowest Bd values, in an apple orchard with organic fertilization (poultry litter) compared to chemical fertilization in the southern region of Brazil.

For the volumetric water content, there were significant interactions at all applied tensions (Table 3). The organic treatment showed the highest average values for the volumetric water content at the surface layer at all applied tensions, except for the $600 \mathrm{kPa}$ matric potential, which was equal to the common urea treatment. At the layer of $0.05-0.10 \mathrm{~m}$ depth, for the 6.60 and $600 \mathrm{kPa}$ matric potentials, the treatment with common urea and the control showed, respectively, the highest and lowest values. For this layer, organic and pelletized urea treatments obtained intermediate values. For the other 
layers, no differences were observed between the treatments. In depth, differences were verified only for the organic treatment, which showed the highest values at the superficial layer.

Table 3. Sliced interaction for water volumetric content by treatment and layer from the 0 to $600 \mathrm{kPa}$ tension.

\begin{tabular}{|c|c|c|c|c|c|}
\hline \multirow{2}{*}{ Treatment } & \multicolumn{4}{|l|}{ Layer (m) } & \multirow{2}{*}{ Statistic } \\
\hline & $0.0-0.05$ & $0.05-0.10$ & $0.10-0.15$ & $0.15-0.20$ & \\
\hline & \multicolumn{4}{|c|}{ Water volumetric content $\left(\mathrm{cm}^{3} \mathrm{~cm}^{-3}\right) 0 \mathrm{kPa}$} & \\
\hline Organic & $0.63 \mathrm{Aa}$ & $0.52 \mathrm{Ab}$ & $0.49 \mathrm{Ab}$ & $0.51 \mathrm{Ab}$ & \\
\hline Common Urea & $0.53 \mathrm{Ba}$ & $0.52 \mathrm{Aa}$ & $0.51 \mathrm{Aa}$ & $0.50 \mathrm{Aa}$ & $C V(\%)=6.4$ \\
\hline Pelleted urea & $0.50 \mathrm{Ba}$ & $0.49 \mathrm{Aa}$ & $0.51 \mathrm{Aa}$ & $0.51 \mathrm{Aa}$ & F test $=3.1^{* *}$ \\
\hline \multirow[t]{2}{*}{ Control } & $0.53 \mathrm{Ba}$ & $0.52 \mathrm{Aa}$ & $0.52 \mathrm{Aa}$ & $0.52 \mathrm{Aa}$ & \\
\hline & \multicolumn{4}{|c|}{ Water volumetric content $\left(\mathrm{cm}^{3} \mathrm{~cm}^{-3}\right) 0.6 \mathrm{kPa}$} & \\
\hline Organic & $0.50 \mathrm{Aa}$ & $0.41 \mathrm{ABb}$ & $0.40 \mathrm{Ab}$ & $0.40 \mathrm{Ab}$ & \\
\hline Common Urea & $0.40 \mathrm{Ba}$ & $0.46 \mathrm{Aa}$ & $0.39 \mathrm{Aa}$ & $0.38 \mathrm{Aa}$ & $C V(\%)=11.3$ \\
\hline Pelleted urea & $0.37 \mathrm{Ba}$ & $0.39 \mathrm{ABa}$ & $0.39 \mathrm{Aa}$ & $0.38 \mathrm{Aa}$ & F test $=2.6^{*}$ \\
\hline \multirow[t]{2}{*}{ Control } & $0.38 \mathrm{Ba}$ & $0.38 \mathrm{Ba}$ & $0.40 \mathrm{Aa}$ & $0.42 \mathrm{Aa}$ & \\
\hline & \multicolumn{4}{|c|}{ Water volumetric content $\left(\mathrm{cm}^{3} \mathrm{~cm}^{-3}\right) 6 \mathrm{kPa}$} & \\
\hline Organic & $0.47 \mathrm{Aa}$ & $0.39 \mathrm{Aab}$ & $0.38 \mathrm{Aab}$ & $0.37 \mathrm{Ab}$ & \\
\hline Common Urea & $0.37 \mathrm{Ba}$ & $0.44 \mathrm{Aa}$ & $0.36 \mathrm{Aa}$ & $0.36 \mathrm{Aa}$ & $C V(\%)=13.2$ \\
\hline Pelleted urea & $0.33 \mathrm{Ba}$ & $0.36 \mathrm{Aa}$ & $0.37 \mathrm{Aa}$ & $0.36 \mathrm{Aa}$ & F test $=2.34^{*}$ \\
\hline \multirow[t]{2}{*}{ Control } & $0.33 \mathrm{Ba}$ & $0.35 \mathrm{Aa}$ & $0.37 \mathrm{Aa}$ & $0.39 \mathrm{Aa}$ & \\
\hline & \multicolumn{4}{|c|}{ Water volumetric content $\left(\mathrm{cm}^{3} \mathrm{~cm}^{-3}\right) 60 \mathrm{kPa}$} & \\
\hline Organic & $0.43 \mathrm{Aa}$ & $0.36 \mathrm{ABab}$ & $0.35 \mathrm{Aab}$ & $0.34 \mathrm{Ab}$ & \\
\hline Common Urea & $0.33 \mathrm{Ba}$ & $0.41 \mathrm{Aa}$ & $0.33 \mathrm{Aa}$ & $0.33 \mathrm{Aa}$ & $C V(\%)=14.7$ \\
\hline Pelleted urea & $0.28 \mathrm{Ba}$ & $0.33 \mathrm{ABa}$ & $0.33 \mathrm{Aa}$ & $0.32 \mathrm{Aa}$ & F test $=2.5^{*}$ \\
\hline \multirow[t]{2}{*}{ Control } & $0.29 \mathrm{Ba}$ & $0.31 \mathrm{Ba}$ & $0.34 \mathrm{Aa}$ & $0.36 \mathrm{Aa}$ & \\
\hline & \multicolumn{4}{|c|}{ Water volumetric content $\left(\mathrm{cm}^{3} \mathrm{~cm}^{-3}\right) 600 \mathrm{kPa}$} & \\
\hline Organic & $0.40 \mathrm{Aa}$ & $0.33 \mathrm{ABa}$ & $0.32 \mathrm{Aa}$ & $0.32 \mathrm{Aa}$ & \\
\hline Common Urea & $0.31 \mathrm{ABa}$ & $0.39 \mathrm{Aa}$ & $0.30 \mathrm{Aa}$ & $0.31 \mathrm{Aa}$ & $\mathrm{CV}(\%)=16.6$ \\
\hline Pelleted urea & $0.26 \mathrm{Ba}$ & $0.31 \mathrm{ABa}$ & $0.30 \mathrm{Aa}$ & $0.30 \mathrm{Aa}$ & F test $=2.04^{*}$ \\
\hline Control & $0.26 \mathrm{Ba}$ & $0.29 \mathrm{Ba}$ & $0.31 \mathrm{Aa}$ & $0.34 \mathrm{Aa}$ & \\
\hline
\end{tabular}

The highest average values of water volumetric content observed in organic treatment may be associated with higher microporosity values (Figure 1). As a result, the water becomes more strongly adhered to the micropores, so that at the end of the application of the same tension, the treatment with organic fertilization remains with greater water content. It is observed that the control treatment, which had more macropores, was the treatment that showed the lowest average values of water volumetric content comparing to the common urea treatment at the layer of 0.05-0.10 m depth since the tension necessary to remove water of these larger pores is smaller than that required to drain micropores.

The common urea and organic fertilization treatments showed the most positive responses for the soil physical attributes. In addition, the highest average apple yields were observed in these treatments (Oliveira et al, 2014), which were $29.6 \mathrm{Mg} \mathrm{ha}^{-1}$ for common urea and
29.0 $\mathrm{Mg} \mathrm{ha}^{-1}$ for organic fertilization, whereas the control and pelleted urea treatments showed yields of 22.8 and $24.8 \mathrm{Mg} \mathrm{ha}^{-1}$, respectively.

\section{Conclusions}

The use of organic fertilization with pig deep-litter in an apple orchard improved the soil physical attributes, promoting the increase of soil total porosity, microporosity, GMDad, water volumetric content, as well as reduction of soil bulk density comparing to the other treatments at the layer of 0.0-0.05 $\mathrm{m}$ depth.

The use of organic fertilization and common urea did not alter the macroporosity values and penetration resistance, however, these treatments showed lower macroporosity values comparing to the control treatment and lower penetration resistance comparing to pelleted urea.

The use of nitrogen sources in an apple orchard increased the GMDws comparing to the control treatment at the soil superficial layer. 


\section{References}

ACATE. Associação Catarinense de Empresas de Tecnologia. Agronegócio e tecnologia. Santa Catariana. Anuário 2014, 96p. Disponível em: <http://www.acate.com.br/sites/default/files/ anuarioacate_0.pdf>.

Amarante, C.V.T., Rosa, E.F.F., Albuquerque, J.A., Klauberg Filho, O., Steffens, C.A. 2015. Atributos do solo e qualidade de frutos nos sistemas convencional e orgânico de produção de maçãs no Sul do Brasil. Revista Ciência Agronomica 46:99-109.

Andreola, F., Costa, L.M., Olszevski, N. 2000. Influência da cobertura vegetal de inverno e da adubação orgânica e, ou, mineral sobre as propriedades físicas de uma terra roxa estruturada. Revista Brasileira de Ciência do Solo 24:857-865.

Arruda, C.A.O., Alves, M.V., Mafra, A.L., Cassol, P.C., Albuquerque, J.A., Santos, J.C.P. 2010. Aplicação de dejeto suíno e estrutura de um Latossolo Vermelho sob semeadura direta. Ciência e Agrotecnologia 34:804-809.

Bronick, C.J., Lal, R. 2005. Soil structure and management: a review. Geoderma 124:3-22.

Carey, P.L., Benge, J.R., Haynes, R.J. 2009. Comparison of soil quality and nutrient budgets between organic and conventional kiwifruit orchards. Agriculture, Ecosystems \& Environment 132:7-15.

Comin, J.J., Loss, A., Veiga, M., Guardini, R., Schmitt, D.E., Oliveira, V., Armando, P., Belli Filho, P., Couto, R.R., Benedet, L., Müller Júnior, V., Brunetto, G. 2013. Physical properties and organic carbon content of a Typic Hapludult soil fertilised with pig slurry and pig litter in a no-tillage system. Soil Research 51:459-470.

Comissão de Química e Fertilidade do Solo CQFS-RS/SC. 2004. Manual de adubação e calagem para os estados do Rio Grande do Sul e Santa Catarina. 10 $0^{a}$.ed. Porto Alegre: Sociedade Brasileira de Ciência do Solo.

Empresa Brasileira de Pesquisa Agropecuária Embrapa. 2013. Sistema brasileiro de classificação de solos. $3^{a}$.ed. Embrapa, Rio de Janeiro, Brasil. $353 p$.

Espanhol, G.L., Albuquerque, J.A., Mafra, A.L., Nuernberg, N.J., Nava, G. 2007. Propriedades químicas e físicas do solo modificadas pelo controle de ervas e adubação orgânica em macieira. Revista de Ciências Agroveterinárias 7:83-94.

GLOVER, J. D. et al. Systematic method for rating soil quality of conventional, organic, and integrated apple orchards in Washington State.
Agriculture, Ecosystems and Environment Oxford, v.80, p.29-45, 2000.

Holb, I.J., Dremákb, P., Bitskeyb, K., Gondab, I. 2012. Yield response, pest damage and fruit quality parameters of scab-resistant and scab-susceptible apple cultivars in integrated and organic production systems. Scientia Horticulturae 145:109-117.

IBGE - Instituto Brasileiro de Geografia e Estatística. Cidades - Lavoura Permanente. 2011. Disponível em: http://www.ibge.com.br/. Acesso em: 07 ago 2013.

Luciano, R.V., Albuquerque, J.A., Mafra, A.L., Costa, A., Grah, J. 2014. Water storage variability in a vineyard soil in the southern highlands of Santa Catarina State. Revista Brasileira de Ciência do Solo 38: 82-93.

Maluche-Baretta, C.R.D., Klauberg-Filho, O., Amarante, C.V.T., Ribeiro, G.M., Almeida, D. 2007. Atributos microbianos e químicos do solo em sistemas de produção convencional e orgânico de maçãs no Estado de Santa Catarina Revista Brasileira de Ciência do Solo 31:655-665.

Martins, C.R., Melo, G.W., Faria, J.L.C. 2008. Modificação química no solo em pomares de macieiras conduzidos em quatro diferentes sistemas de produção frente às características naturais dos seus entornos. Revista Brasileira de Agrociência 14:128-131.

Moreti, D., Alves, M.C., Perozini, A.C., Paz Gonzáles, A., Silva, E.C. 2006. Condutividade hidráulica e resistência à penetração do solo influenciada por diferentes sistemas de manejo. Cadernos do laboratorio xeoloxico de laxe 11:2328.

Oliveira, B.S., Ambrosini, V.G., Lovato, P.E., Comin, J.J., Ceretta, C.A., Santos Junior, E., Santos, M.A., Lazzari, C.J.R., Bruneto, G. 2014. Produção e nitrogênio no solo e na solução em pomar de macieira submetido à aplicação de fontes de nutrientes. Ciência Rural 44:2164-2170.

Peck, G.M., Merwin, I.A., Thies, J.E., Schindelbeck, R.R., Brown, M.G. 2011. Soil properties change during the transition to integrated and organic apple production in a New York orchard. Appled Soil Ecology 48:18-30.

Richart, A., Tavares Filho, J., Brito, O.R., Llanillo, R.F., Ferreira, R. 2005. Compactação do solo: causas e efeitos. Semina: Ciencias Agrárias 26:321-344.

Silva, M.A.S., Mafra, A.L., Albuquerque, J.A., Rosa, J.D., Bayer, C., Mielniczuk, J. 2006. Propriedades físicas e teor de carbono orgânico de um Argissolo Vermelho sob distintos sistemas de uso e manejo. Revista Brasileira de Ciência do Solo 30:329-337. 
Souza, I.A., Ribeiro, K.G., Rocha, W.W., Pereira, O.G., Cecon, P.R. 2013. Physical properties of a Red-Yellow Latosol and productivity of a signalgrass pasture fertilized with increasing nitrogen doses. Revista Brasileira de Ciência do Solo 37:1549-1556.

Veiga, M. 2001. Metodologia para coleta de amostras e análises físicas do solo. Epagri, Florianópolis, Brasil. 52p. (Boletim técnico, 156)

Vezzani, F.M., Mielniczuk, J. 2009. Uma visão sobre qualidade do solo. Revista Brasileira de Ciência do Solo 33:743-755. 